UDC 635.757:631.559.2:51-76

DOI https://doi.org/10.32851/2226-0099.2020.113.11

\title{
FENNEL (FOENICULUM VULGARE MILL.) YIELD PREDICTION USING A REGRESSION MODEL
}

\author{
Makukha O.V. - Candidate of Agricultural Sciences, \\ Associate Professor at the Department of Botany and Plant Protection, \\ Kherson State Agrarian and Economic University
}

Fennel (Foeniculum vulgare Mill.) belonging to the Apiaceae family is a valuable medicinal, spice, aromatic, melliferous, vegetable and ornamental plant. A successful cultivation of fennel in the southern Steppe of Ukraine requires scientific modelling and prediction of the seed yield, taking into account different parameters of the technological practices and their effect on the productive processes of plants.

The field experiments were carried out in 2011-2013 in the Kherson region on the dark chestnut soils typical for the southern Steppe of Ukraine. The experimental design included the following factors and their variants: Factor $A$ - nutrition background: without fertilizers; $N_{30} ; N_{60} ; N_{90}$; Factor $B$ - sowing date: early (the third ten-day period of March at the right soil tilth stage); mid-time (the first ten-day period of April); late (the second ten-day period of April); Factor $C$-row spacing, cm: $15 ; 30 ; 45 ; 60$.

The model testing was conducted in 2014-2019 on the farms of Kherson region. According to the results of regression analysis, a multiple linear regression model of fennel seed productivity depending on the studied technological practices was created: $Y=7.2302+0.0024 X_{-}-0.0039 X_{2}+$ $0.0012 X_{3}$, where $Y$-fennel seed yield, t/ha; $X_{1}$ - nutrition background (rate of nitrogen fertilizers), $\mathrm{kg}$ reactant/ha; $X_{2}$ - sowing date (the sum of effective temperatures above $10^{\circ} \mathrm{C}$ ), ${ }^{\circ} \mathrm{C} ; \mathrm{X}_{3}-$ row spacing, cm. A comparison of the experimental yield data and the values of the yielding capacity, calculated using the regression equation, confirmed the accuracy of the created multiple linear regression model of the fennel seed productivity.

The range of variation in the residual seed yield, depending on the interaction of the investigated parameters of the technological practices, was $0.11 \ldots+0.16 \mathrm{t} / \mathrm{ha}$. In most variants, difference indicator between the true and modelled values of crop productivity was within limits of \pm 0.05 t/ha.

The results of the developed model application in agricultural enterprises of the region confirm the relevance of a mathematical approach to increasing the seed productivity of common fennel and reducing the potential yield losses. The introduction of statistical methods into the technology of fennel cultivation is a promising strategy for crop productivity improvement.

Key words: fennel, cultivation technology, seed yield, multiple linear regression model, statistical analysis, model testing.

Макуха О.В. Прогнозування врожаю фенхелю звичайного (Foеniculum vulgare Mill.) з використанням регресійної моделі

Фенхель (Foeniculum vulgare Mill.) - цінна лікарська, пряносмакова, ароматична, медоносна, овочева та декоративна рослина родини Аріасеае. Успішне вирошування фенхелю в південному Степу України вимагає наукового моделювання $і$ прогнозування врожаю насіння з урахуванням різних параметрів технологічних заходів $і$ їх впливу на продукційні прочеси рослин.

Польові досліди проводились у 2011-2013 роках в Херсонській області на темно-каштанових трунтах, типових для південного Степу Украӥни. Схема досліду включала такі фактори та їх варіанти: фактор $A-$ фон живлення: без добрив; $N_{30} ; N_{60} ; N_{90}$; фактор $B$ - строк сівби: ранній (третя декада березня, при настанні фізичноі стиглості трунту); середній (периа декада квітня); пізній (друга декада квітня); фактор С- иирина міжряддя, см: 15; 30; 45; 60.

Виробнича перевірка розробленої моделі проводилась у 2014-2019 роках у фермерських господарствах Херсонської області. За результатами статистичного аналізу створено модель множинної лінійної регресї насіннєвої продуктивності фенхелю звичайного залежно від досліджуваних технологічної заходів: $Y=7,2302+0,0024 X_{1}-0,0039 X_{2}+$

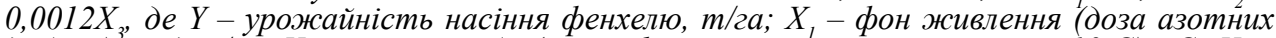
добрив), кг д.р./га; $X_{2}-$ строк сівби (сума ефективних температур вище $10^{\circ} \mathrm{C}$ ), ${ }^{\circ} \mathrm{C} ; \mathrm{X}_{3}-$ иирина міжряддя, см. 
Порівняння експериментальних даних $і$ значень урожайності, розрахованих за допомогою рівняння регресії, підтвердило точність розробленої моделі насіннєвої продуктивності культури. Діапазон варіювання різниці фактичної та змодельованої врожайності становив 0,11 .. + 0,16 m/га залежно від взаємодії досліджуваних параметрів технологічних заходів, у більшості варіантів знаходився в межах $\pm 0,05 \mathrm{~m} / 2$.

Результати застосування розробленої моделі в сільськогосподарських підприємствах регіону підтверджують актуальність математичного підходу до підвищення насінневої продуктивності фенхелю $і$ зменшення потенційних втрат урожаю. Впровадження статистичних методів у технологію вирощування фенхелю звичайного є перспективною стратегією покращення показників продуктивності культури.

Ключові слова: фенхель звичайний, технологія вирощування, урожай насіння, модель множинної лінійної регресії, статистичний аналіз, перевірка моделі.

Problem formulation. Fennel (Foeniculum vulgare Mill.) belonging to the Apiaceae family is a valuable medicinal, spice, aromatic, melliferous, vegetable and ornamental plant. It finds application in official and folk medicine, cooking, food, pharmaceutical, perfume and cosmetics and other industries, as well as in veterinary medicine, animal husbandry [1, p. 3, 2; p. 1578].

Fennel has now been naturalized and cultivated for commercial purposes throughout the world [3, p. 83]. Foeniculum vulgare is one of the most commonly used and extensively studied medicinal herbs in the world due to its economic importance and significant pharmaceutical industry applications [4, p. 2, 5; p. 237]. An increased interest in the improvement of agricultural yield of fennel has encouraged the cultivation of the plant on large scale. In many countries of the world, considerable attention has been paid to improving the growing technology of this crop [1, p. 4, 6; p. 1505].

A successful cultivation of fennel in the southern Steppe of Ukraine requires scientific modelling and prediction of the seed yield, taking into account different parameters of the technological practices and their effect on the productive processes of plants.

Analysis of recent research and publications. One of the most popular mathematical methods of statistical analysis and development of simple models is linear regression, which finds application in solving diverse practical and theoretical tasks [7, p. 32]. In agricultural science, linear regression models are frequently used for the statistical data evaluation and forecasting [8, p. 47; 9, p. 125]. The general purpose of regression analysis is to determine the relationship between several independent variables and a dependent variable [9, p. 128; 10, p. 897]. Regression models are applied for crop yield prediction depending on the cultivation technology elements, soil properties, nutrition and water use efficiency, weather parameters, etc. [11, p. 83; 12, p. 46; 13, p. 212].

The multiple linear regression model creating will ensure yield prediction of common fennel in the context of the influence of nitrogen fertilizers doses, sowing dates and row spacing, as well as formation of abundant sustainable fennel yields, and a reduction of its possible losses by providing the most favourable interaction of the above mentioned agrotechnical practices. Consequently, mathematical modelling is important for efficient agronomic management in the cultivation of fennel. The introduction of the elaborated multiple linear regression model into growing technology of fennel will allow increasing the interest of farmers in this promising, highly profitable crop. The cultivation of common fennel, even on small areas, will significantly improve the performance of the agricultural enterprises in the region, especially farms [14, p. 109].

Task formulation. The field experiments were carried out in the period from 2011 to 2013 on the fields of Kherson Regional State Centre for Plant Variety Examination (latitude $46^{\circ} 43^{\prime} 5^{\prime \prime} \mathrm{N}$ and longitude $32^{\circ} 38^{\prime} 23^{\prime} \mathrm{E}$ ). The study was devoted to determining the effect of doses of nitrogen fertilizers, sowing dates, and row spacing on the fennel seed yield under the arid conditions of the southern Steppe of Ukraine (Fig. 1). 


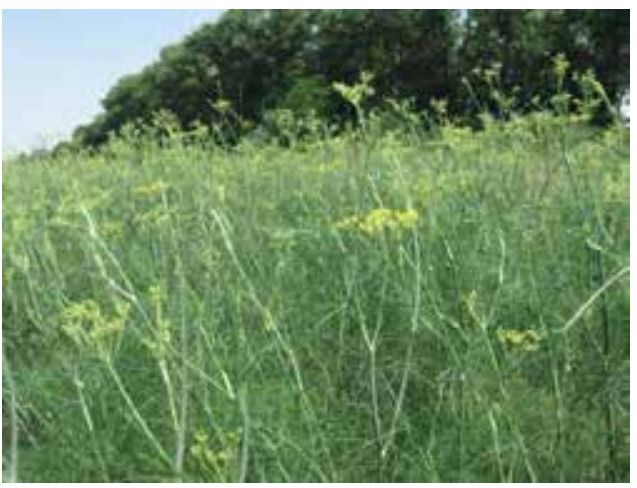

$a$

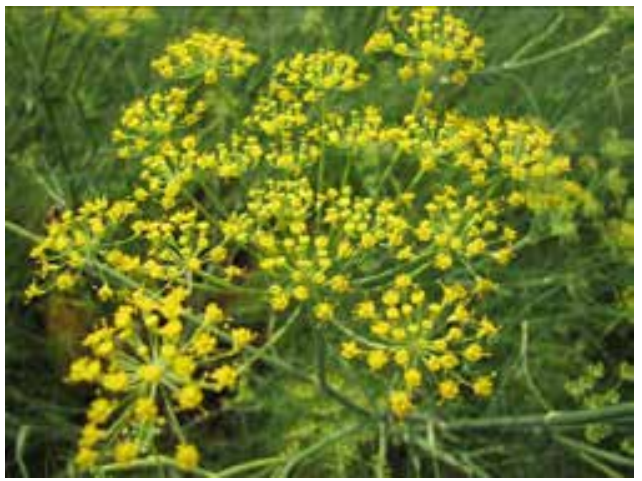

$c$

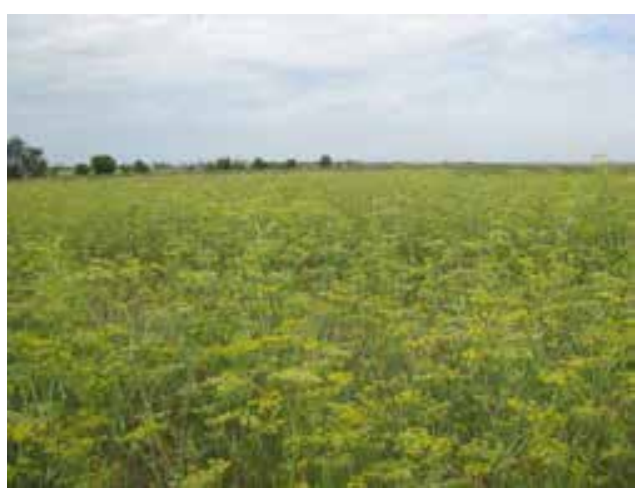

$b$

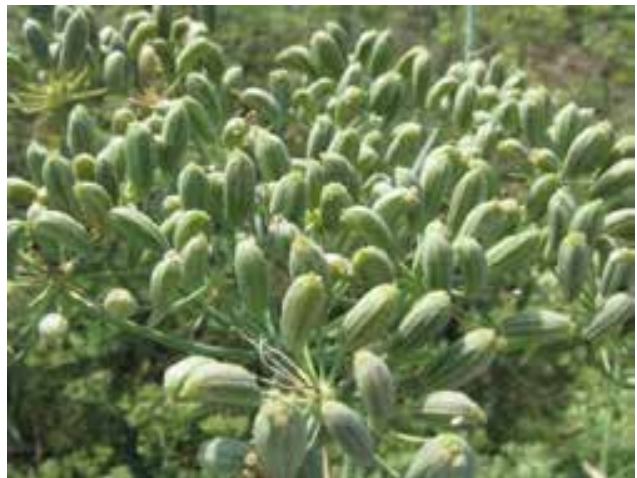

$d$

Fig. 1. The field experiment with fennel: a-fennel field in the phase of stem formationflowering, $b$-fennel field in the phase of flowering-fruit formation, $c$-the productive umbel of fennel in the phase of flowering, $d$-the productive umbel of fennel in the phase of ripening

The experimental design included the following factors and their variants: Factor $\mathrm{A}-$ nutrition background: without fertilizers; $\mathrm{N}_{30} ; \mathrm{N}_{60} ; \mathrm{N}_{90} ;$ Factor $\mathrm{B}$ - sowing date: early (the third ten-day period of March at the right soil tilth stage); mid-time (the first ten-day period of April); late (the second ten-day period of April); Factor $\mathrm{C}$ - row spacing, cm: $15 ; 30 ; 45 ; 60$. The field experiments were carried out in accordance with the generally accepted requirements and recommendations [15, p. 38-200]. The trial was based on a split plot method with a four-fold replication. The sown area of the third-order elementary plot was $70 \mathrm{~m}^{2}$; the record plot was $55 \mathrm{~m}^{2}$.

The soil of the experimental plot is dark chestnut weakly alkaline medium loamy, typical for the southern steppe zone of Ukraine. The arable layer of the soil contains humus (2.28\%), nitrates (26), movable phosphorus (34), and exchangeable potassium (250 mg/kg of soil), $\mathrm{pH}$ of water extract (7.0-7.2).

The climate of the zone is moderately continental, hot and dry, characterized by low and unevenly distributed precipitation, low air humidity, frequent droughts and strong dry winds, a lot of heat and light. The sum of active temperatures above $10^{\circ} \mathrm{C}$ is $3200-$ $3400^{\circ} \mathrm{C}$, average annual precipitation is $340-400 \mathrm{~mm}$, and the hydrothermal coefficient is $0.5-0.7$. The weather conditions during the years of research differed somewhat in 
the temperature regime, amount and distribution of atmospheric precipitation, but overall were typical for the zone. The most favourable conditions for the growth and development of fennel plants were observed in 2011, satisfactory and moderate conditions were recorded in 2012 and 2013, respectively (Table 1).

Table 1

The weather conditions during the years of research

\begin{tabular}{|l|c|c|c|c|c|c|c|c|c|}
\hline \multirow{3}{*}{ Months } & \multicolumn{3}{|c}{$\begin{array}{c}\text { Air temperature, } \\
\text { 'C }\end{array}$} & \multicolumn{3}{|c|}{$\begin{array}{c}\text { Precipitation amounts, } \\
\text { mm }\end{array}$} & \multicolumn{3}{c|}{$\begin{array}{c}\text { Air humidity, } \\
\text { \% }\end{array}$} \\
\cline { 2 - 11 } & $\mathbf{2 0 1 1}$ & $\mathbf{2 0 1 2}$ & $\mathbf{2 0 1 3}$ & $\mathbf{2 0 1 1}$ & $\mathbf{2 0 1 2}$ & $\mathbf{2 0 1 3}$ & $\mathbf{2 0 1 1}$ & $\mathbf{2 0 1 2}$ & $\mathbf{2 0 1 3}$ \\
\hline January & -2.8 & -1.7 & -0.4 & 25.5 & 70.8 & 29.6 & 90 & 86 & 92 \\
\hline February & -3.8 & -7.4 & 2.3 & 10.6 & 20.9 & 19.6 & 79 & 80 & 85 \\
\hline March & 2.4 & 2.5 & 3.1 & 3.8 & 25.6 & 38.8 & 74 & 77 & 76 \\
\hline April & 9.7 & 13.2 & 11.9 & 39.1 & 5.9 & 3.7 & 65 & 70 & 66 \\
\hline May & 16.8 & 20.8 & 20.7 & 36.7 & 39.6 & 0.3 & 67 & 63 & 58 \\
\hline June & 21.4 & 23.4 & 23.0 & 76.2 & 20.1 & 79.1 & 65 & 58 & 63 \\
\hline July & 24.7 & 26.6 & 23.2 & 11.0 & 40.2 & 44.1 & 62 & 50 & 60 \\
\hline August & 22.3 & 23.6 & 24.2 & 5.4 & 79.2 & 12.4 & 56 & 57 & 52 \\
\hline September & 18.4 & 19.1 & 15.1 & 17.1 & 1.6 & 43.7 & 59 & 64 & 71 \\
\hline October & 9.5 & 14.7 & 9.3 & 7.0 & 27.6 & 53.9 & 72 & 76 & 84 \\
\hline November & 2.2 & 6.6 & 7.5 & 1.0 & 7.1 & 4.0 & 72 & 87 & 86 \\
\hline December & 3.8 & -0.9 & 0.5 & 50.3 & 35.0 & 3.7 & 88 & 88 & 82 \\
\hline Annual & $\mathbf{1 0 . 4}$ & $\mathbf{1 1 . 7}$ & $\mathbf{1 1 . 7}$ & $\mathbf{2 8 3 . 7}$ & $\mathbf{3 7 3 . 6}$ & $\mathbf{3 3 2 . 9}$ & $\mathbf{7 1}$ & $\mathbf{7 1}$ & 73 \\
\hline
\end{tabular}

The generally accepted agricultural practices of fennel cultivation were used, except for the factors and variants studied. Winter wheat was the preceding crop in the experiment. The seeding rate was $5 \mathrm{~kg} / \mathrm{ha}$, seeding depth $-3-4 \mathrm{~cm}$. The fennel seeds were harvested when the fruits reached maturity on the central umbel and first-order umbels. Harvesting and yield registration were done according to the relevant methods [15, p. 38-200].

The multi-factor analysis of variance (ANOVA) of the fennel yield data was performed by using the standard methodology within AgroStat add-on for Microsoft Excel software application [16, p. 75]. Statistical evaluation was performed for the reliability level of $95 \%(\mathrm{p}<0.05)$.

The fennel seed productivity was modelled by the results of the multiple linear regression analysis (MLR). It was conducted by using the common calculations by the method of the least squares within Microsoft Excel software [17, p. 52-59; 18, p. 27]. The model of the fennel seed yield was developed as a common linear function $\mathrm{Y}=\mathrm{b}_{0}+$ $\mathrm{b}_{1} \mathrm{X}_{1}+\mathrm{b}_{2} \mathrm{X}_{2}+\ldots+\mathrm{b}_{\mathrm{n}} \mathrm{X}_{\mathrm{n}}$. The studied factors were expressed in mathematical form: nutrition background - in kilograms of the active ingredient of nitrogen fertilizers per ha, sowing dates - in the sum of effective temperatures above $10^{\circ} \mathrm{C}$, needed for seed ripening, row spacing - in centimetres.

A comparative analysis of the true and modelled yielding capacity of common fennel was done to determine the accuracy of prediction. The model testing was conducted in 2014-2019 on the fields of Nadiia farm of Velyka Oleksandrivka district, Dawn farm of Vysokopillia district and other agricultural enterprises of Kherson region. 
Research results. The research results showed that the elements of the growing technology such as doses of nitrogen fertilizers, sowing dates, and row spacing are important measures for managing the seed productivity of common fennel. The yielding capacity of the fennel seeds changed in the context of variants from 0.72 to $1.38 \mathrm{t} / \mathrm{ha}$ (Table 2).

The least favourable conditions for the productive processes of plants were obtained on the plots without fertilizers application, when fennel was sown in the second decade of April with a row spacing of $15 \mathrm{~cm}$. The highest values of the fennel seed yield at 1.35 and $1.38 \mathrm{t} / \mathrm{ha}$ were recorded in the variants of the interaction of early spring sowing, row spacing of $45 \mathrm{~cm}$, nitrogen fertilizers of 60 and $90 \mathrm{~kg}$ of the active ingredient per ha, respectively. An increase in the dose of nitrogen fertilizers from 60 to $90 \mathrm{~kg}$ reactant/ha ensured an insignificant growth of the studied parameter of $0.03 \mathrm{t} / \mathrm{ha}(2.2 \%)$.

Table 2

\section{Seed yield of fennel depending on the factors under study, $t / \mathrm{ha}$} (average for 2011-2013)

\begin{tabular}{|c|c|c|c|c|c|c|c|}
\hline \multirow{2}{*}{$\begin{array}{c}\text { Nutrition } \\
\text { background, } \\
\text { factor } \mathrm{A}\end{array}$} & \multirow{2}{*}{$\begin{array}{c}\text { Sowing } \\
\text { date, } \\
\text { factor } B\end{array}$} & \multicolumn{4}{|c|}{ Row spacing, cm, factor $\mathrm{C}$} & \multicolumn{2}{|c|}{$\begin{array}{c}\text { Average } \\
\text { for factors }\end{array}$} \\
\hline & & 15 & 30 & 45 & 60 & $\mathbf{A}$ & $\mathbf{B}$ \\
\hline \multirow{3}{*}{$\begin{array}{l}\text { Without } \\
\text { fertilizers }\end{array}$} & early & 0.93 & 1.01 & 1.06 & 0.96 & \multirow{3}{*}{0.87} & 1.15 \\
\hline & mid-time & 0.80 & 0.88 & 0.94 & 0.83 & & 0.99 \\
\hline & late & 0.72 & 0.78 & 0.83 & 0.74 & & 0.87 \\
\hline \multirow{3}{*}{$\mathrm{N}_{30}$} & early & 1.04 & 1.14 & 1.22 & 1.08 & \multirow{3}{*}{0.99} & \\
\hline & mid-time & 0.91 & 0.98 & 1.07 & 0.93 & & \\
\hline & late & 0.80 & 0.88 & 0.95 & 0.83 & & \\
\hline \multirow{3}{*}{$\mathrm{N}_{60}$} & early & 1.12 & 1.24 & 1.35 & 1.17 & \multirow{3}{*}{1.06} & \\
\hline & mid-time & 0.98 & 1.06 & 1.15 & 1.01 & & \\
\hline & late & 0.85 & 0.94 & 1.01 & 0.89 & & \\
\hline \multirow{3}{*}{$\mathrm{N}_{90}$} & early & 1.15 & 1.27 & 1.38 & 1.20 & \multirow{3}{*}{1.08} & \\
\hline & mid-time & 0.99 & 1.08 & 1.18 & 1.03 & & \\
\hline & late & 0.85 & 0.95 & 1.03 & 0.89 & & \\
\hline \multicolumn{2}{|c|}{ Average for factor $\mathrm{C}$} & 0.93 & 1.02 & 1.10 & 0.96 & \multicolumn{2}{|c|}{1.00} \\
\hline \multicolumn{8}{|c|}{$\begin{array}{l}\mathrm{LSD}_{05}, \mathrm{t} / \mathrm{ha} \text { (assessment of significance of partial differences): } \mathrm{A}=0.029 ; \mathrm{B}=0.041 ; \\
\mathrm{C}=0.029\end{array}$} \\
\hline \multicolumn{8}{|c|}{$\begin{array}{l}\mathrm{LSD}_{05}, \mathrm{t} / \mathrm{ha} \text { (assessment of significance of mean (main) effects): } \mathrm{A}=0.008 ; \mathrm{B}=0.010 ; \\
\mathrm{C}=0.008\end{array}$} \\
\hline
\end{tabular}

Note: $L S D_{05}$ - the least significant difference.

On average, by factor A, application of the investigated doses of nitrogen fertilizers led to an increase of the yielding capacity by $13.8-24.1 \%$. The degree of influence of the sowing dates on the crop productivity was, on average, by factor B, 16.2-32.2\%. Changing the row spacing resulted in $3.2-18.3 \%$ increase of the mean factor value of this indicator.

The mathematical processing of fennel yield data allowed to define the coefficients of correlation, determination, and regression, as well as to determine the effect of different cultivation technology elements on the crop productivity. When the mathematical model was created, the studied factors were used as independent variables $\left(\mathrm{X}_{1}, \mathrm{X}_{2}, \mathrm{X}_{3}\right)$, 
and the fennel seed yield was used as a dependent variable (Y). All the inputs were expressed in a digital quantitative form to ensure correct data processing.

The statistical analysis proved the high strength of ties between the factors under investigation and the yielding capacity of the fennel seeds. A multiple correlation coefficient (R) was close to 1.0 and made up 0.9477 (Table 3).

Table 3

\section{Correlation and regression analysis of the fennel seed yield depending on the factors under study}

\begin{tabular}{|c|c|c|c|}
\hline Related $\mathbf{X}_{\mathbf{i}}$ & $\begin{array}{c}\mathbf{R} \text { - multiple and } \\
\mathbf{r}_{\mathbf{i}}-\text { pair correlation } \\
\text { coefficients }\end{array}$ & $\begin{array}{c}\mathbf{D} \text { - general and } \\
\mathbf{d}_{\mathbf{i}}-\text { partial coefficients } \\
\text { of determination }\end{array}$ & $\begin{array}{c}\mathbf{b}_{\mathbf{0}} \text { and } \mathbf{b}_{\mathbf{i}} \text { - regres- } \\
\text { sion coefficients }\end{array}$ \\
\hline $\mathrm{X}_{1} \mathrm{X}_{2} \mathrm{X}_{3}$ & 0.9477 & 0.8981 & 7.2302 \\
\hline $\mathrm{X}_{1}$ & 0.7159 & 0.5123 & 0.0024 \\
\hline $\mathrm{X}_{2}$ & -0.8517 & 0.7254 & -0.0039 \\
\hline $\mathrm{X}_{3}$ & 0.3658 & 0.1339 & 0.0012 \\
\hline
\end{tabular}

Note: $X_{1}$ - nutrition background (dose of nitrogen fertilizers), $\mathrm{kg}$ of the active ingredient per ha (factor A); $X_{2}$ - sowing date (the sum of effective temperatures above $10^{\circ} \mathrm{C}$ ), ${ }^{\circ} \mathrm{C}$ (factor $B) ; X_{3}$ - row spacing, $\mathrm{cm}$ (factor $C$ )

The factor of nutrition background had a strong positive effect on the fennel seed yield $(r=0.7159)$. The high degree of influence of the nitrogen fertilizers on the seed productivity of common fennel can be connected with the low content of nitrogen in the dark chestnut soils of the southern Steppe of Ukraine. Nitrogen is the first most commonly used plant nutrient in agriculture. It plays a key role in increasing of crop yield [19, p. 211].

A strong negative linear statistical relationship was revealed between the sowing dates, expressed in mathematical form as the sum of effective temperatures above $10^{\circ} \mathrm{C}$, and the crop productivity. The coefficient of correlation for the above mentioned factor amounted to -0.8517 . An increase in the sum of effective temperatures with a delay in sowing is associated with a decrease in the yielding capacity. The seed productivity of fennel reduced from early to late sowing. Under the moisture deficiency conditions of the southern Steppe ofUkraine, the sowing dates indirectly influence the moisture supply of fennel sprouts, as well as affect the hydrothermal environment of the phases of growth and development [20,p. 238]. Postponing sowing from the third ten-day period of March to the first-second decade of April led to deterioration in the conditions for the productive processes of plants. It is connected with adverse impact of the summer drought on the flowering and fruits formation, and that of autumn rains on maturing [21, p. 77].

The correlation analysis indicates a moderate positive statistical relationship between the row spacing and the fennel seed yield. The correlation coefficient for these variables was 0.3658 . Changing the inter-row width, which is accompanied by the changes in the intra-row spacing and the form of the plant nutrition area, can affect the growth and development of the crop, as well as the conditions for the moisture and nutrients absorption by the plants.

Thus, among the factors studied, the dates of sowing had the most significant effect on the crop productivity under arid conditions of the southern Steppe of Ukraine. The general coefficient of determination reached the value of 0.8981 . This indicates sufficiently high accuracy and reliability of the developed mathematical model. 
According to the results of regression analysis the multiple linear regression model of fennel seed productivity depending on the studied technological practices was created:

$$
\mathrm{Y}=7.2302+0.0024 \mathrm{X}_{1}-0.0039 \mathrm{X}_{2}+0.0012 \mathrm{X}_{3}
$$

where $\mathrm{Y}$ - fennel seed yield, $\mathrm{t} / \mathrm{ha} ; \mathrm{X}_{1}$ - nutrition background (dose of nitrogen fertilizers), $\mathrm{kg}$ reactant/ha; $\mathrm{X}_{2}$ - sowing date (the sum of effective temperatures above $\left.10^{\circ} \mathrm{C}\right),{ }^{\circ} \mathrm{C} ; \mathrm{X}_{3}$ - row spacing, $\mathrm{cm}$.

The model shows that an increase of the dose of nitrogen fertilizers on $1 \mathrm{~kg} / \mathrm{ha}$ lead to an increase in the yielding capacity of fennel on $2.4 \mathrm{~kg} / \mathrm{ha}$. The growth of the crop productivity under the influence of an inter-row widening on $1 \mathrm{~cm}$ can be equal to $1.2 \mathrm{~kg} / \mathrm{ha}$. However, an increase in the sum of effective temperatures on $1^{\circ} \mathrm{C}$ causes a reduction in the fennel seed yield on $3.9 \mathrm{~kg} / \mathrm{ha}$.

The results of variance analysis allowed determining the peculiarities in the influence of investigated agrotechnical measures on the seed productivity of common fennel. The factor of sowing date with the share of $43.4 \%$ had the strongest influence on the yielding capacity of the crop. The doses of nitrogen fertilizers can also be considered as a determinant factor for fennel seed yield. Its share was $28.4 \%$. The degree

Table 4

\section{A comparison of the true and modelled seed yield of fennel depending} on the factors under study, t/ha

\begin{tabular}{|c|c|c|c|c|c|}
\hline $\begin{array}{c}\text { Nutrition } \\
\text { background, } \\
\text { factor } \mathrm{A}\end{array}$ & $\begin{array}{l}\text { Sowing date, } \\
\text { factor } B\end{array}$ & $\begin{array}{l}\text { Row spacing, } \\
\text { cm, factor C }\end{array}$ & $\begin{array}{l}\text { True seed } \\
\text { yield }\end{array}$ & $\begin{array}{l}\text { Modelled } \\
\text { seed yield }\end{array}$ & $\begin{array}{l}\text { Residual } \\
\text { seed yield }\end{array}$ \\
\hline \multirow{12}{*}{$\begin{array}{l}\text { Without } \\
\text { fertilizers }\end{array}$} & \multirow{4}{*}{ early } & 15 & 0.93 & 1.01 & -0.08 \\
\hline & & 30 & 1.01 & 1.03 & -0.02 \\
\hline & & 45 & 1.06 & 1.05 & 0.01 \\
\hline & & 60 & 0.96 & 1.06 & -0.10 \\
\hline & \multirow{4}{*}{ mid-time } & 15 & 0.80 & 0.86 & -0.06 \\
\hline & & 30 & 0.88 & 0.88 & 0 \\
\hline & & 45 & 0.94 & 0.90 & 0.04 \\
\hline & & 60 & 0.83 & 0.91 & -0.08 \\
\hline & \multirow{4}{*}{ late } & 15 & 0.72 & 0.74 & -0.02 \\
\hline & & 30 & 0.78 & 0.75 & 0.03 \\
\hline & & 45 & 0.83 & 0.77 & 0.06 \\
\hline & & 60 & 0.74 & 0.79 & -0.05 \\
\hline \multirow{12}{*}{$\mathrm{N}_{30}$} & \multirow{4}{*}{ early } & 15 & 1.04 & 1.08 & -0.04 \\
\hline & & 30 & 1.14 & 1.10 & 0.04 \\
\hline & & 45 & 1.22 & 1.12 & 0.10 \\
\hline & & 60 & 1.08 & 1.14 & -0.06 \\
\hline & \multirow{4}{*}{ mid-time } & 15 & 0.91 & 0.93 & -0.02 \\
\hline & & 30 & 0.98 & 0.95 & 0.03 \\
\hline & & 45 & 1.07 & 0.97 & 0.10 \\
\hline & & 60 & 0.93 & 0.98 & -0.05 \\
\hline & \multirow{4}{*}{ late } & 15 & 0.80 & 0.81 & -0.01 \\
\hline & & 30 & 0.88 & 0.82 & 0.06 \\
\hline & & 45 & 0.95 & 0.84 & 0.11 \\
\hline & & 60 & 0.83 & 0.86 & -0.03 \\
\hline
\end{tabular}


Table 4 (continuance)

\begin{tabular}{|c|c|c|c|c|c|}
\hline \multirow{12}{*}{$\mathrm{N}_{60}$} & \multirow{4}{*}{ early } & 15 & 1.12 & 1.15 & -0.03 \\
\hline & & 30 & 1.24 & 1.17 & 0.07 \\
\hline & & 45 & 1.35 & 1.19 & 0.16 \\
\hline & & 60 & 1.17 & 1.21 & -0.04 \\
\hline & \multirow{4}{*}{ mid-time } & 15 & 0.98 & 1.00 & -0.02 \\
\hline & & 30 & 1.06 & 1.02 & 0.04 \\
\hline & & 45 & 1.15 & 1.04 & 0.11 \\
\hline & & 60 & 1.01 & 1.06 & -0.05 \\
\hline & \multirow{4}{*}{ late } & 15 & 0.85 & 0.88 & -0.03 \\
\hline & & 30 & 0.94 & 0.90 & 0.04 \\
\hline & & 45 & 1.01 & 0.91 & 0.10 \\
\hline & & 60 & 0.89 & 0.93 & -0.04 \\
\hline \multirow{12}{*}{$\mathrm{N}_{90}$} & \multirow{4}{*}{ early } & 15 & 1.15 & 1.22 & -0.07 \\
\hline & & 30 & 1.27 & 1.24 & 0.03 \\
\hline & & 45 & 1.38 & 1.26 & 0.12 \\
\hline & & 60 & 1.20 & 1.28 & -0.08 \\
\hline & \multirow{4}{*}{ mid-time } & 15 & 0.99 & 1.07 & -0.08 \\
\hline & & 30 & 1.08 & 1.09 & -0.01 \\
\hline & & 45 & 1.18 & 1.11 & 0.07 \\
\hline & & 60 & 1.03 & 1.13 & -0.10 \\
\hline & \multirow{4}{*}{ late } & 15 & 0.85 & 0.95 & -0.10 \\
\hline & & 30 & 0.95 & 0.97 & -0.02 \\
\hline & & 45 & 1.03 & 0.98 & 0.05 \\
\hline & & 60 & 0.89 & 1.00 & -0.11 \\
\hline
\end{tabular}

of effect of the row spacing on the crop productivity made up $17.0 \%$. The total share of the interaction of the factors under study amounted to $8.9 \%$. The share of occasional influence of other unaccounted factors was $2.3 \%$.

A comparison of the experimental yield data and the values of the yielding capacity, calculated using the regression equation, confirmed accuracy of the created multiple linear regression model of the fennel seed productivity (Table 4).

The range of variation in the residual seed yield, depending on the interaction of the investigated parameters of the technological practices, was $0.11 \ldots+0.16 \mathrm{t} / \mathrm{ha}$. In most variants, difference indicator between the true and modelled values of the crop productivity was within limits of $\pm 0.05 \mathrm{t} / \mathrm{ha}$.

The statistical model examination conducted in the period from 2014 to 2019 in the farms of Kherson region allowed evaluating its effectiveness in the context potentially using in agricultural science and practice for the prediction of the fennel seed yield. The value of the modelled yielding capacity changed during the years of testing from 0.97 to $1.18 \mathrm{t} / \mathrm{ha}$. The actual seed productivity of the crop reached $0.93-1.13 \mathrm{t} / \mathrm{ha}$ and was lower compared to the estimated indicator by 0.04-0.07 t/ha.

Crop yield prediction is important for agricultural planning and resource distribution decision making. It is a difficult task because crop production is influenced by a great variety of interrelated factors. Agricultural management specialists need simple and accurate estimation techniques such as regression models to predict crop yields in the planning process $[22$, p. $101 ; 23$, p. 6]. 
Regression models are successfully created and used for yield forecasting of wheat, barley, maize and many other crops [9, p. $127 ; 10$, p. $901 ; 13$, p. 216]. It is possible to evaluate the share of all independent variables included in the model. All the inputs should be easily available for agricultural producers without special research [9, p. 130]. Regression models provide a sufficiently high level of accuracy in prediction, the possibility of simulation in the current year, before harvest [8, p. 19; 9, p. 129]. An accurate and timely forecast of yields is the basis for estimating production volumes during the harvest, planning farm work and risk management $[9$, p. 127; 23, p. 7].

The results of the developed model application in agricultural enterprises of the region confirm the relevance of a mathematical approach to increase the seed productivity of common fennel and reduction the potential yield losses.

Conclusions. The multiple linear regression model of the fennel seed yield depending on the nitrogen fertilizers doses, sowing dates and row spacing is characterized by the following advantages: a simple and quick calculation, available initial data, a high enough level of prediction accuracy, the use in agricultural enterprises of the southern Steppe of Ukraine, the ability to determine the cultivation efficiency.

There is a need to create mathematical models of the yielding capacity of common fennel specific to various regions, accepted agricultural practices of its cultivation, different variants of the interaction of the growing technology elements. The introduction of statistical methods into the technology of fennel cultivation is a promising strategy for the improvement of the crop productivity.

\section{REFERENCES:}

1. Badgujar S.B., Patel V.V., Bandivdekar A.H. Foeniculum vulgare Mill.: a review of its botany, phytochemistry, pharmacology, contemporary application, and toxicology. BioMed Research International. 2014. Vol. 2014, Article ID 842674. P. 1-32. doi: $10.1155 / 2014 / 842674$.

2. Foeniculum vulgare: a comprehensive review of its traditional use, phytochemistry, pharmacology, and safety / Rather M.A., Dar B.A., Sofi S.N., Bhat B.A., Qurishi M.A. Arabian Journal of Chemistry. 2016. Vol. 9. P. 1574-1583.

3. Al-Snafi A.E. The chemical constituents and pharmacological effects of Foeniculum vulgare - a review. IOSR Journal of Pharmacy. 2018. Vol. 8(5). P. 81-96.

4. Therapeutic and pharmacological potential of Foeniculum vulgare Mill.: a review / Kooti W., Moradi M., Ali-Akbari S., Sharafi-Ahvazi N., Asadi-Samani M., AshtaryLarky D. Journal of HerbMed Pharmacology. 2015. Vol. 4(1). P. 1-9.

5. An insight of multitudinous and inveterate pharmacological applications of Foeniculum vulgare (fennel): pharmacology and therapeutic uses / Syed F.Q., Mirza M.B., Elkady A.I., Hakeem K.R., Alkarim S. Plant and Human Health. 2019. Vol. 3(11). P. 231-250. doi: 10.1007/978-3-030-04408-4 11.

6. Singh D. On-farm assessment of technological innovation of fennel (Foeniculum vulgare Mill.) cultivation. International Journal of Current Microbiology and Applied Sciences. 2017. Vol. 6(7). P. 1504-1509. doi: 10.20546/ijcmas.2017.607.180.

7. Kutner M.H., Nachtsheim C., Neter J. Applied linear regression models. McGrawHill, Irwin, 2004. 178 p.

8. Mead R., Curnow R.N., Hasted A.M. Statistical methods in agriculture and experimental biology. Boca Raton : Chapman and Hall, CRC Press, 2017. 123 p.

9. Niedbala G. Application of multiple linear regression for multi-criteria yield prediction of winter wheat. Journal of Research and Applications in Agricultural Engineering. 2018. Vol. 63(4). P. 125-131.

10. Mokarram M., Bijanzadeh E. Prediction of biological and grain yield of barley using multiple regression and artificial neural network models. Australian Journal of Crop Science. 2016. Vol. 10(6). P. 895-903. doi: 10.21475/ajcs.2016.10.06.p7634. 
11. Wu X., Bao W. Statistical analysis of leaf water use efficiency and physiology traits of winter wheat under drought condition. Journal of Integrative Agriculture. 2012. Vol. 11(1). P. 82-89.

12. Paltasingh K.R., Goyari P. Statistical modeling of crop-weather relationship in India: a survey on evolutionary trend of methodologies. Asian Journal of Agriculture and Development. 2018. Vol. 15(1). P. 43-60.

13. Micskei G., Arendas T., Berzsenyi Z. Relationships between maize yield and growth parameters in a long-term fertilization experiment. Acta Agronomica Hungarica. 2012. Vol. 60(3). P. 209-219. doi: 10.1556/AAgr.60.2012.3.4.

14. Макуха О.В. Економічна ефективність вирощування фенхелю звичайного залежно від агротехнічних заходів в умовах півдня України. Таврійський науковий вісник. 2019. Вип. 105. С. 102-109.

15. Основи наукових досліджень в агрономії / Єщенко В.О., Копитко П.Г., Костогриз П.В., Опришко В.П. Вінниця : Едельвейс і К, 2014. С. 38-200.

16. Kim H.-Y. Analysis of variance (ANOVA) comparing means of more than two groups. Restorative Dentistry \& Endodontics. 2014. Vol. 39(1). P. 74-77. doi: 10.5395/ rde.2014.39.1.74.

17. Draper N.R., Smith H. Applied regression analysis. New-York City : John Wiley \& Sons, 2014. 96 p.

18. Seber G.A.F., Lee A.J. Linear regression analysis. New-York City : John Wiley \& Sons, 2012. 117 p.

19. Role of nitrogen for plant growth and development: a review / Leghari S.J., Wahocho N.A., Laghari G.M., Laghari A.H., Bhabhan G.M., Talpur K.H. Advances in Environmental Biology. 2016. Vol. 10(9). P. 209-218.

20. Makukha O. The impact of biopreparations and sowing dates on the productivity of fennel (Foeniculum vulgare Mill.). Journal of Ecological Engineering. 2020. Vol. 21(4). P. 237-244. doi: 10.12911/22998993/119802.

21. Макуха О.В. Особливості формування сухої речовини фенхелю звичайного залежно від агротехнічних заходів в умовах півдня України. Таврійський науковий вісник. 2018. Вип. 99. С. 76-83.

22. Paswan R.P., Begum S.A. Regression and neural networks models for prediction of crop production. International Journal of Scientific \& Engineering Research. 2013. Vol. 4(9). P. 98-108.

23. Gonzalez-Sanchez A., Frausto-Solis J., Ojeda-Bustamante W. Attribute selection impact on linear and nonlinear regression models for crop yield prediction. Hindawi. 2014. Vol. 2014, Article ID 509429. P. 1-10. doi: 10.1155/2014/509429. 